\title{
Chemical Constituents, Larvicidal Effects and Radical Scavenging Activity of Tetracera breyniana Schltdl. (Dilleniaceae)
}

\author{
Cinthia C. de Lima ${ }^{a}$, Rosangela P. Lyra Lemos ${ }^{b}$, Lucia M. Conserva ${ }^{a} *$ \\ a Instituto de Química e Biotecnologia, Universidade Federal de Alagoas, 57072-970, Maceió-AL, Brazil. \\ ${ }^{\mathrm{b}}$ Instituto do Meio Ambiente do Estado de Alagoas, 57017-320, Maceió-AL, Brazil.
}

\author{
ARTICLE INFO \\ Article history: \\ Received on: 09/07/2013 \\ Revised on: 29/07/2013 \\ Accepted on: 14/09/2013 \\ Available online: 30/09/2013 \\ Key words: \\ Tetracera breyniana, Aedes \\ aegypti, Flavonols, \\ Terpenoids, Larvicidal, \\ DPPH.
}

\begin{abstract}
Extracts and fractions from the leaves and stems of Tetracera breyniana Schltdl. were evaluated against the fourth instar Aedes aegypti larvae and ability to scavenge free radicals. Fractions that provided the best results were fractionated on silica gel column to afforded three flavonoils (quercetin, 7-O-methylquercetin and 7-Omethylkaempferol) and two terpenoids ( $\beta$-sitosterol and betulinic acid). These compounds were identified on basis of their physical and NMR spectral data and by comparison with literature data. With exception of quercetin, all other compounds are been described for the first time in the investigated species. In the larvicidal assays, when compared to synthetic insecticide Temephos, only hexane fraction from stem was effective $\left(\mathrm{LD}_{50}\right.$ $72.08 \mu \mathrm{g} / \mathrm{mL}$ ). In the DPPH assays, EtOAc fractions from the leaves $\left(\mathrm{CI}_{50} 74.15 \pm 14.73 \mu \mathrm{g} / \mathrm{mL}\right)$ and stem $\left(\mathrm{IC}_{50}\right.$ $39.87 \pm 13.46 \mu \mathrm{g} / \mathrm{mL}$ ), of which quercetin was isolated, showed the best results when compared with the positive standards used while $\mathrm{CHCl}_{3}$ fractions of both plant parts, of which methylated flavonols were isolated, showed only a moderate activity. Possibly these constituents are responsible in part for the radical scavenging activities observed. Subsequently, evaluation of all isolated compounds will be needed to confirm the active component.
\end{abstract}

\section{INTRODUCTION}

Dengue is a major public health problem in the world. According to World Health Organization (WHO) estimates, 0.5 million people with dengue hemorrhagic fever (DHF) require hospitalization each year and approximately $2.5 \%$ of these individuals die from DHF (WHO, 2008). Annually, there may be over 50-100 million dengue infections in tropical and subtropical areas (Renjana and Thoppil, 2013), and so these diseases have emerged as a major international health problem and a notable increase in dengue cases $(77.7 \%$ ) has been reported by Brazilian health authorities (Oliveira et al., 2010).

In recent years, there has been a global trend toward the use of natural substances present in vegetables and other sources as antioxidant. Several of these substances may interfere with the oxidation process by reacting with free radicals (Silva et al., 2010). When these species had an excessive formation induces oxidative damage to biomolecules, which eventually causes numerous diseases (Gülçin et al., 2006; Edewor-Kuponiyi, 2013).

\footnotetext{
* Corresponding Author

Instituto de Química e Biotecnologia, Universidade Federal de Alagoas, 57072-970, Maceió-AL, Brazil; Tel: +55 82 3214-1390.
}

The family Dilleniaceae comprises 10-14 genera and ca. 500 species, with a pantropical and subtropical distribution (Kubitzi, 2004; Horn, 2009). In the Neotropics are found 102 species distributed in six genera Curatella, Davilla, Doliocarpus, Neodillenia, Pinzona, and Tetracera (Bruniera and Groppo, 2010). In Brazil, 82 species of these genera are present in these genera (Fraga and Stehmann, 2010). According to Horn (2007), this family is divided into four subfamilies and the genus Tetracera, belonging to subfamily Delimoideae, contains about 45 species with a pantropical distribution. Species of this genus have been used in folk medicine for the treatment of various diseases and infections (Tona et al., 2004; Nguyen et al., 2004; Fenner et al., 2010; Umar et al., 2010; Lawal et al., 2011) and several biological properties such as antiplasmodial (Tona et al., 2004), antimycobacterial (Lowal et al., 2011), anti-HIV and antireverse transcriptase (Kwon et al., 2012), anti-hyperglycemic (Umar et al., 2010), antioxidant (Kukongviriyapan et al., 2003; Lock et al., 2005), anti-ulcerogenic (Fenner et al., 2006; Oluwole et al., 2008), DNA polymerase $\beta$ inhibition (Ma et al., 1999), glucose-uptake activity (Lee et al., 2009), and xanthine oxidase inhibition (Nguyen et al., 2004) were reported. 
Chemical investigations carried out with active extracts of different Tetracera species have reported mainly the isolation of flavonoids (Gurni et al., 1981; Gurni and Kubitzi, 1981; Na et al., 2001; Lee et al., 2009) and terpenoids (Dan and Dan, 1980; Ma et al., 1999; Na et al., 2001; Subramanyam et al., 2009) and studies have showed that some of these compounds possess important biological activities (Ma et al., 1999; Subramanyam et al., 2009; Nguyen and Nguyen, 2013). T. breyniana Schltdl., known as "cipó-de-fogo", is a creeper whose leaf decoction is used in Brazil against lymphatic problems (Souza, 2000). From the leaves of this species, besides proanthocyanidin some common flavonols (azaleatin, kaempferol, 5-methylkaempferol, and quercetin), glycoside (quercetin 3-O-galactopyranoside) and sulphates (kaempferol 3-sulphate and quercetin 3-sulphate) have been isolated (Gurni and Kubitzki, 1981). This work was undertaken in order to determine the phytochemicals, larvicidal effects and free radical scavenging activity of the extracts from the leaves and stem of this species. Among isolated compounds, with exception of quercetin, this work report for the first time the presence of 7-Omethylquercetin and 7-O-methylkaempferol, and terpenoids (betulinic acid and $\beta$-sitosterol) as well as evaluation of larvicidal and radical scavenging activities in the investigated species.

\section{MATERIAL AND METHODS}

\section{Plant Material}

Leaves and stem of $T$. breyniana were collected in the Área de Proteção Ambiental de Santa Rita, Marechal Deodoro, AL, Brazil, in May 2008 and identified by Rosangela P. de Lyra
Lemos of the Instituto do Meio Ambiente do Estado de Alagoas (IMA-AL), where a voucher specimen (MAC-23840) was deposited.

\section{Extraction and Isolation}

The air-dried leaves $(350 \mathrm{~g})$ and stems $(820 \mathrm{~g})$ were extracted with $90 \% \mathrm{EtOH}$ at room temperature. The EtOH extracts (leaves: $36.1 \mathrm{~g}$; stems: $17.9 \mathrm{~g}$ ) were suspended in $\mathrm{MeOH}-\mathrm{H}_{2} \mathrm{O}$ (3:2) and extracted with hexane, $\mathrm{CHCl}_{3}$ and EtOAc. Subsequently, both extracts and fractions from partition were evaluated against fourth instar of $A$. aegypti larvae and as free radical scavengers (DPPH). Fractions with promising results in the assays were further fractionated. Hexane $(4.6 \mathrm{~g}), \mathrm{CHCl}_{3}(4.4 \mathrm{~g})$ and EtOAc (2.2 g) fractions from leaves after successive chromatographic fractionations over silica gel with hexane-EtOAc and Sephadex LH-20 with MeOH afforded, respectively, $\beta$-sitosterol [1 (10 mg); Macari et al., 1990], 7-O-methylquercetin [2 (10 mg); mp 286.2$289.7^{\circ} \mathrm{C}$ (Kim, 2005)] and quercetin [3 (11 mg); Kim, 2005]. $\mathrm{CHCl}_{3}$ fraction from stems (2.2 g) was chromatographed on silica gel column with hexane-EtOAc to provide, after recrystallizations with $\mathrm{MeOH}$, betulinic acid [4 (20 mg); mp 285.3-287.2 ${ }^{\circ} \mathrm{C}$; Mahato and Kundu, 1994] and 7-O-methylkaempferol [5; $10 \mathrm{mg}$ ) (Pizzolatti et al., 2003; Silva et al., 2009].

The structures of the compounds (1-5) (Fig. 1) were identified by their physical (mp) and by interpretation of their spectral data $\left({ }^{1} \mathrm{H}\right.$ and ${ }^{13} \mathrm{C}$ NMR, including DEPT, HSQC and HMBC experiments) and by the comparison with those reported in literature.<smiles>CCC(CC[C@@H](C)C1CCC2C3CC=C4CC(O)CC[C@]4(C)C3CC[C@@]21C)C(C)C</smiles><smiles>[R20]c1cc(O)c2c(=O)c(O)c(-c3ccc(O)c([R])c3)oc2c1</smiles><smiles>C=C(C)[C@@H]1CCC2(C(=O)O)CC[C@]3(C)[C@@H](CC[C@H]4[C@@]5(C)CCC(O)[C@H](C)[C@@H]5CC[C@]43C)[C@@H]12</smiles>

Fig. 1: Isolated compounds from T. breyniana. 


\section{Larvicidal assays}

Fourth instar of A. aegypti larvae, aged four to six days, were collected from a mosquito colony maintained at insectaria of the Instituto de Química e Biotecnologia da Universidade Federal de Alagoas. The mosquitoes were kept at $27.1 \pm 4^{\circ} \mathrm{C}$ and $69.9 \pm$ $7.8 \%$ relative humidity and photoperiod of approximately $12 \mathrm{~h}$. The hatching of larvae occurred in distilled water, and the feeding of adult insects was made with anhydrous glucose solution to $10 \%$ in cotton balls changed daily. The blood supply for the females was performed using the species pigeons Columbia livia. Larvicidal assays were performed following the recommendations of the WHO (1981) with some modifications (Oliveira et al., 2010). Initially all samples were screened at $250 \mu \mathrm{g} / \mathrm{mL}$. Based on the percent mortality values (mortality $\geq 75 \%$ ), LD50 values in micrograms per milliliter and their $95 \%$ fiducial limits of upper and lower confidence limits of the samples were determined.

\section{Statistical analysis}

The average larval mortality data were subjected to probit analysis for calculating $\mathrm{LD}_{50}$, and other statistics at $95 \%$ fiducial limits of upper and lower confidence limits were calculated by using Probit analysis of Finney (1971).

\section{Free radical scavenging activity (DPPH)}

These assays for all samples were conducted in triplicate, according to the methods described by Silva et al. (2010). Samples and standards were measured at $515 \mathrm{~nm}$, using at least five different concentrations (12.5 to $100 \mu \mathrm{g} / \mathrm{mL}$ ), against a blank (MeOH HPLC grade). In a cuvette, $0.1 \mathrm{~mL}$ of the samples was mixed with $0.9 \mathrm{~mL} \mathrm{DPPH} \bullet$ dissolved in $\mathrm{MeOH}(100 \mu \mathrm{mol} / \mathrm{L})$ and the absorbance was monitored for $1 \mathrm{~h}$.

The percentage inhibition was calculated using the equation, (\%) $=\left[\left(\mathbf{A b s}_{\text {control }}-\mathbf{A b s}_{\text {samples }}\right) / \mathbf{A b s}_{\text {control }}\right] \mathbf{x} \mathbf{1 0 0}$, and $\mathrm{IC}_{50}$ values were estimated by a nonlinear regression algorithm using Origin $^{\mathrm{TM}}$ version 7.0 (Micronal, Northampton, MA, USA). Data were analyzed by ANOVA followed by Tukey test $(p<0.05)$. Ascorbic acid and BHT were used as controls.

\section{RESULTS AND DISCUSSION}

In the preliminary larvicidal assays, among the extracts tested only one of them showed $100 \%$ mortality against fourth instar A. aegypti larvae. All other no caused mortality $(\leq 25 \%)$ after $48 \mathrm{~h}$ exposure. As shown in Table 1, when compared to synthetic insecticide Temephos $\left(\mathrm{LD}_{50} 8.7 \mu \mathrm{g} / \mathrm{mL}\right)$, only hexane fraction from stem $\left(\mathrm{LD}_{50} 72.08 \mu \mathrm{g} / \mathrm{mL} ; 95 \% \mathrm{CL}\right.$ 60.92-82.47) was effective. All others were inactive $\left(\mathrm{LD}_{50}>280 \mu \mathrm{g} / \mathrm{mL}\right.$; results not shown in Table 1) (Oliveira et al., 2010). The isolation and purification of this extract and evaluation of these compounds will be needed to identify the active component.

Despite significant advances in the techniques used for mosquitoes control during recent decades, it continues to pose serious public health problems and many infectious diseases for humans and animals such as malaria, dengue fever, yellow fever, filariasis, and others can be transmitted by vectors. $A$. aegypti acts as a vector for the arboviruses responsible for yellow fever and also for dengue and dengue fevers (Garcez et al., 2009). Since there is no vaccine currently available for dengue and DHF prevention, the eradication of the mosquito adults and larvae, which is primarily relied on applications of synthetic insecticides or larvicides, is the most commonly adopted strategy for reducing morbidity (WHO, 2008). According to the literature, the organophosphate temephos is one of the most employed commercial insecticides for the control of this vector (Macoris et al., 2007; Garcez et al., 2009; Oliveira et al., 2010). However, these chemicals can affect non target population and may increase mosquito resistance to insecticides. So, plants may be an alternative source of mosquito control agents because they constitute a rich source of bioactive chemicals.

In this study, free radical scavenging activity of extract and fractions from $T$. breyniana, as well as of the standards used (ascorbic acid and BHT) were evaluated by DPPH. As shown in Table 1, among the extracts tested, with exception of hexane fractions from the leaves and stems, all other samples tested showed significant antioxidant activity $\left(\mathrm{IC}_{50}<350.78 \pm 2.71\right.$ $\mu \mathrm{g} / \mathrm{mL}$ ) and the best results were obtained with the EtOAc fractions from the leaves $(74.15 \pm 14.73 \mu \mathrm{g} / \mathrm{mL})$ and stems $(39.87$ $\pm 13.46 \mu \mathrm{g} / \mathrm{mL}$ ), with $\mathrm{IC}_{50}$ values comparable to standards used, of which quercetin (3) was isolated. Comparatively, $\mathrm{CHCl}_{3}$ fractions of both parts of the plant showed only a moderate activity (Table 1). These fractions, less hydroxylated flavonoids (7-Omethylquercetin and 7-O-methylkaempferol) were isolated. Subsequently, evaluation of all isolated compounds will be needed to confirm the active component.

Table. 1: Effects of extracts and fractions against forth instar A. aegypti larvae and DPPH.

\begin{tabular}{|c|c|c|c|}
\hline $\begin{array}{l}\text { Plant } \\
\text { part }\end{array}$ & $\begin{array}{c}\text { Extracts and } \\
\text { fractions }\end{array}$ & $\begin{array}{c}\text { A. aegypti } \\
\mathrm{LD}_{50}(\mu \mathrm{g} / \mathrm{mL})^{\mathrm{a}}\end{array}$ & $\begin{array}{c}\text { DPPH } \\
\text { IC }_{50} \pm \text { DP }(\mu \mathrm{g} / \mathrm{mL})\end{array}$ \\
\hline Leaves & Crude EtOH & & $195.23 \pm 1.30$ \\
\hline & Hexane & & NT \\
\hline & $\mathrm{CHCl}_{3}$ & & $155.93 \pm 3.87$ \\
\hline & EtOAc & & $74.15 \pm 14.73$ \\
\hline & $\mathrm{MeOH}-\mathrm{H}_{2} \mathrm{O}$ & & $123.45 \pm 2.22$ \\
\hline \multicolumn{4}{|l|}{ Stem } \\
\hline & Crude EtOH & \multirow[b]{2}{*}{$\begin{array}{c}72.08 \text { (95\% CL 60.92- } \\
82.47)\end{array}$} & $350.78 \pm 2.71$ \\
\hline & Hexane & & $2911.31 \pm 1.20$ \\
\hline & $\mathrm{CHCl}_{3}$ & & $192.33 \pm 1.58$ \\
\hline & EtOAc & & $39.87 \pm 13.46$ \\
\hline & $\mathrm{MeOH}-\mathrm{H}_{2} \mathrm{O}$ & & $106.77 \pm 4.38$ \\
\hline & Ascorbic acid & \multirow{4}{*}{8.7 (95\% CL 7.0-10.2) } & \multirow{4}{*}{$\begin{array}{l}37.37 \pm 3.18 \\
97.86 \pm 2.52\end{array}$} \\
\hline & ВНT & & \\
\hline & Formulate & & \\
\hline & Temephos & & \\
\hline
\end{tabular}

$\mathrm{CL}=$ confidence limits (lower and upper confidence limits). ${ }^{a}$ Mean value of three replicates; $\mathrm{LD}_{50}$ lethal dose that kills $50 \%$ of the exposed larvae; $\mathrm{NT}=$ not tested.

Many studies have shown that antioxidant properties, especially radical scavenging activities, are very important due to the deleterious role of free radicals in foods and in biological systems (Gülçin et al., 2006) and antioxidant capacity is widely 
used as a parameter to characterize food or medicinal plants and their bioactive components (Silva et al., 2010). The hydroxyl radical which is a very reactive species that is formed in biological systems has been implicated as a highly damaging species in free radical pathology, capable of damaging almost every molecule found in living cells. Hydroxyl radical scavenging capacity of an extract is directly related to its antioxidant activity (EdeworKuponiyi, 2013). According Silva et al. (2010), anti-radical activities of plant extracts are often associated with the presence of polyphenol compounds, like flavonoids, which have an important role in stabilizing lipid oxidation.

\section{CONCLUSION}

There are no reports on larvicidal and radical scavenging activities to species studied. The results of this study showed that hexane fraction from stem of $T$. breyniana possess potential for control of mosquito A. aegypti and open the possibility of further investigations on the efficacy of the larvicidal properties of plant product extracts. This study also showed that some extracts were effectively able to inhibit the formation of free radicals. Among the extracts tested, the best radical scavenging activities was found mainly by the most polar extracts and in some case, this activity was comparable with that of BHT or ascorbic acid. Although there is the possibility that the tannins and others pigments takes a role in scavenging activity, previous studies showed that the effects of some extracts seem to be correlated with the presence of phenolic compounds such as flavonoids. Then, among compounds isolated, quercetin, 7-O-methylkaempferol, 7-O-methylquercetin may mediate the radical scavenging activity observed in the extracts from leaves and stem of T. breyniana.

\section{ACKNOWLEDGMENTS}

The authors thank to CNPq, FAPEAL, MCT-IMSEAR, and $\mathrm{BNB}$ for the financial support.

\section{REFERENCES}

Bruniera CP, Groppo M. Flora da Serra do Cipó, Minas Gerais: Dilleniaceae. Bol Bot Univ São Paulo, 2010; 28: 59-67.

Dan S, Dan SS. Triterpenoids of Indian Dilleniaceae. J Indian Chem Soc, 1980; 57: 760.

Edewor-Kuponiyi TI. Determination of the total phenolic contents, antimicrobial and antioxidant effects in the ethanolic leaf extract of Prunus amgydalus. J Appl Pharm Sci, 2013; 3: 94-100.

Fenner R, Betti AH, Mentz LA, Rates SMK. Plantas utilizadas na medicina popular brasileira com potencial atividade antifúngica. Rev. Bras. Cienc. Farmac, 2006; 42: 269-394. Cambridge.

Finney DJ. 1971. Probit analysis. Cambridge University Press,

Fraga CN, Stehmann JR. Novidades taxonômicas para Dilleniaceae brasileiras. Rodriguésia, 2010; 61: S01-S06. 2010.

Garcez WS, Garcez FR, da Silva LMGE, Hamerski L. Larvicidal activity against Aedes aegypti of some plants native to the West-Central region of Brazil. Bioresource Technol, 2009; 100: 66476650 .

Gülçin I, Mshvildadze V, Gepdiremen A, Elias R. Screening of antiradical and antioxidant activity of monodesmosides and crude extracts from Leontice smirnowii tuber. Phytomedicine, 2006; 13: 343-351.
Gurni AA, König WA, Kubitzki K. Flavonoid glycosides and sulphates from the Dilleniaceae. Phytochemistry, 1981; 20: 1057-1059.

Gurni AA, Kubitzki K. Flavonoid chemistry and systematic of the Dilleniaceae. Biochem Syst Ecol, 1981; 9: 109-114.

Horn JW. 2007. Dilleniaceae. In: Kubitzki K, ed. Flowering Plants. In The families and genera of vascular Plants. Berlin: Springer Verlag, 132-154.

Horn JW. Phylogenetics of Dilleniaceae using sequence data from four plastid loci ( $r b c L$, infA, rps4, rpll6 intron). Int J Plant Sci, 2009; 170: 794-813.

Kim J. Radical scavenging capacity and antioxidant activity of the e vitamer fraction in Rice bran. Food Chem. Toxicol, 2005; 70: 208213.

Kubitzki K. 2004. Dilleniaceae. In: Smith N, Mori SA, Henderson A, Stevenson DW, Heald SV, eds. Flowering plants of the Neotropics. New York: The New York Botanical Garden, 128-130.

Kukongviriyapan V, Janyacharoen VT, Kukongviriyapan U, Laupattarakasaem P, Kanokmedhakul S, Chantaranothai C. Hepatoprotective and antioxidant activities of Tetracera loureiri. Phytother Res, 2003; 17: 717-721.

Kwon, H.S., Park, J.A., Kim, J-H., You1,J.C. Identification of anti-HIV and anti-Reverse Transcriptase activity from Tetracera scandens. BMB reports, 2012; 45: 165-170.

Lawal TO, Adeniyi BA, Wan B, Franzblau SG, Mahady GB. In-vitro susceptibility of Mycobacterium tuberculosis to extracts of Uvaria afzelli Scott Elliot and Tetracera alnifolia Willd. Afr J Biomed Res, 2011; 14: 17-21.

Lee MS, Kim CH, Hoang DM, Kim BY, Sohn CB, Kim MR, Ahn JS. Genistein-derivatives from Tetracera scandens stimulate glucoseuptake in L6 myotubes. Biol Pharm Bull, 2009; 32: 504-508.

Lock O, Castillo P, Doroteo V, Rojas R. Antioxidant activity in vitro of selected Peruvian medicinal plants. Acta Horticulturae, 2005; 675 .

Ma J, Starck SR, Hecht SM. DNA Polymerase $\beta$ inhibitors from Tetracera boiviniana. J Nat. Prod, 1999; 62: 1660-1663.

Macari PAT, Emerenciano VP, Ferreia ZGMS. Identificação dos triterpenos de Miconia albicans Triana, através de análise por microcomputador. Química Nova, 1990; 13: 260-262.

Macoris M.., Andrighett, MTM, Otrera VCG, Carvalho LR, Caldas Jr AL, Brogdon WG. Association of insecticide use and alteration on Aedes aegypti susceptibility status. Mem Inst Oswaldo Cruz, 2007; 102: 895-900.

Mahato SB, Kundu AP. ${ }^{13} \mathrm{C}$ NMR Spectra of pentaciclic triterpenoids - A compilation some salient features. Phytochemistry, 1994; 47: 1517-1575.

$\mathrm{Na} Z$, Li C, Zheng H, Sun H. Chemical constituents from Tetracera asiatica. Yunnan Zhiwu Yanjiu, 2001; 23: 400-402.

Nguyen MTT, Awale S, Tezuka Y, Tran Q, Watanabe H, Kadota S. Xanthine oxidase inhibitory activity of Vietnamese medicinal plants. Biol Pharm Bull, 2004; 27: 1414-1421.

Nguyen MTT, Nguyen NT. A new lupane triterpene from Tetracera scandens L., xanthine oxidase inhibitor. Nat Prod Res: Formerly Nat Prod Lett, 2013; 27: 61-67.

Oliveira PV, Ferreira Jr. JC, Moura FS, Lima GS, de Oliveira FM, Oliveira PES, Conserva LM, Giulietti AM, Lemos RPL. Larvicidal activity of 94 extracts from ten plant species of northeastern of Brazil against Aedes aegypti L. (Diptera: Culicidae). Parasitol Res, 2010; 107: 403-407.

Oluwole FS, Ayo JA, Omolaso BO, Emikpe BO, Adesanwo JK. Methanolic extract of Tetracera potatoria, an antiulcer agent increases gastric mucus secretion and endogenous antioxidants. Nigerian J Physiol Sci, 2008; 23: 79-83.

Pizzolatti MG, Júnior AC, Szpoganicz B, Souza E. Flavonóides glicosilados das folhas e flores de Bauhinia forficata (Leguminosae). Quim. Nova, 2003; 26: 466-469.

Renjana PK, Thoppil JE. Larvicidal activities of the leaf extracts and essential oil of Premna latifolia Roxb. (Verbenaceae) against Aedes albopictus Skuse (Diptera: Culicidae). J Appl Pharm Sci, 2013; 3: 101-105. 
Silva TMS, Carvalho MG, Braz-Filho R. Estudo espectroscópico em elucidação estrutural de flavonóides de Solanum jabrense Agra \& Nees e S. paludosum Moric. Quim. Nova,2009; 32: $1119-1128$

Silva TBC, T. Souza VK, da Silva APF, Lemos RPL, Conserva LM. Determination of the phenolic content and antioxidant potential of crude extracts and isolated compounds from leaves of Cordia multispicata and Tournefortia bicolor. Pharm Biol, 2010; 48: 63-69.

Souza EA. Dissertation in Plant Sciences, Universidade Federal da Paraíba (PRODEMA) - João Pessoa - PB, Brazil, 2000, 161pp.

Subramanyam R, Goud M, Sudhamalla B, Reddeem E, Gollapudi A, Nellaepalli Yadavalli V, Chinnaboina M, Amooru DG. Novel binding studies of human serum albumin with trans-feruloyl maslinic acid. J Photochem Photobiol B: Biol, 2009; 95: 8188.

Tona L, Cimanga RK, Mesia K, Musuamba CT, De Bruyne T, Apers S, Hernans N, Van Miert S, Pieters L, Totte J, Vlietinck AJ. In vitro antiplasmodial activity of extracts and fractions from seven medicinal plants used in the Democratic Republic of Congo. J Ethnopharmacol, 2004; 93: 27-32.
Umar A, Ahmed QU, Muhammad BY, Dogarai BBS, Soad SZBM. Anti-hyperglycemic activity of the leaves of Tetracera scandens Linn. Merr. (Dilleniaceae) in alloxan induced diabetic rats. J Ethnopharmacol, 2010; 131: 140-145.

WHO (World Health Organization). 1981. Instructions for determining the susceptibility or resistance of mosquito larvae to insecticide. WHO/VBC/81.807:1-6.

World Health Organization (WHO). 2008. Dengue and Dengue Haemorrhagic Fever. Available at: http://www.who.int/mediacentre /factsheets/fs 117/en. [Accessed 08 June 2013].

\section{How to cite this article:}

Cinthia C. de Lima, Rosangela P. Lyra Lemos, Lucia M. Conserva., Chemical Constituents, Larvicidal Effects and Radical Scavenging Activity of Tetracera breyniana Schltdl. (Dilleniaceae). J App Pharm Sci, 2013; 3 (09): 014-018. 